Stanistaw Liszewski

\title{
Rozwój badań geograficznych nad osadnictwem w Polsce w XX i na początku XXI wieku (zarys problematyki badawczej)
}

Badania geograficzne nad osadnictwem mają w Polsce bogate tradycje oraz duży dorobek i należą do najlepiej rozwiniętych wśród subdyscyplin geografii człowieka. W Polsce zainteresowania badawcze, zwłaszcza osadnictwem pasterskim, sięgają początków XX w., a autorstwo pierwszego oryginalnego programu badań dotyczącego geografii miast powszechnie przypisuje się Ludomirowi Sawickiemu (1884-1928), profesorowi Uniwersytetu Jagiellońskiego.

Celem tego opracowania jest prześledzenie tematyki badań nad osadnictwem, prowadzonych przez polskich geografów przez ostatnie 100 lat, czyli praktycznie od początku XX w. aż po rok 2015. Obok identyfikacji głównych prac i odpowiedniego ich sklasyfikowania według kierunków czy nurtów badawczych, autor szuka w tej pracy odpowiedzi na pytanie o ciągłość zainteresowań badawczych geografów podjętą tematyką lub ich zmienność w badanym okresie.

Opracowanie wykorzystuje kwerendę prac i analizę treści publikacji dotyczących geografii osadnictwa, które ukazały się w Polsce $\mathrm{w}$ podanym w tytule okresie. Kwerenda została przeprowadzona w odniesieniu do prac, reprezentujących kilku typów. Były to: prace przeglądowe, podręczniki akademickie, wydawnictwa pokonferencyjne oraz czasopisma i wydawnictwa ciągłe, $w$ których zamieszczane są prace z zakresu geografii osadnictwa. Odrębną grupę stanowiły publikowane prace doktorskie i habilitacyjne.

W tym miejscu warto uświadomić czytelnikowi, że począwszy od lat 90. XX w. publikuje się w Polsce rocznie około 100 prac z zakresu geografii osadnictwa - szacunku dokonano na podstawie pracy 
(Jakóbczyk-Gryszkiewicz, Paradowska 1995). Uwzględniając fakt, że w przeszłości było ich znacznie mniej, i tak można szacować, że w badanym okresie ukazało się ich kilka tysięcy, co przekracza możliwość ich szczegółowego poznania przez jednego badacza. Dlatego autor ma świadomość, że dokonany przez niego wybór prac i przeprowadzona klasyfikacja o charakterze autorskim jest subiektywna.

\section{Źródła i materiały wykorzystane w pracy}

\section{Prace przeglądowe}

Rozwój geografii osadnictwa w Polsce jest szczegółowo i systematycznie monitorowany, co potwierdza dość regularne ukazywanie się artykułów przeglądowych podsumowujących poszczególne okresy badań lub niektóre problemy badawcze. Należy tu zwłaszcza wymienić prace K. Dziewońskiego (1956, 1983, 1990), który dokonując w nich podsumowania badań nad osadnictwem w poszczególnych okresach, jednocześnie wytyczał nowe kierunki badań. Dodając do tego, że Profesor Dziewoński, zwłaszcza w latach 70. XX w., kierował kilkoma Centralnymi Programami Badawczymi $(\mathrm{CPB})$, które dotyczyły polskiego osadnictwa, łatwiej zrozumieć rolę, jaką odegrał w rozwoju badan geograficznych nad osadnictwem w Polsce.

Ważną rolę $\mathrm{w}$ udostępnieniu dorobku polskich geografów zajmujących się badaniem osadnictwa odegrało również trzytomowe wydawnictwo pod wspólnym tytułem Geografia osadnictwa i ludności w niepodległej Polsce. Lata 1918-1993, wydane przez Polskie Towarzystwo Geograficzne pod redakcją S. Liszewskiego (1993, 1994, 1995). Poszczególne tomy publikacji poświęcono: ośrodkom naukowo-badawczym i ich dorobkowi (t. 1.), kierunkom badań (t. 2.) i badaczom (t. 3.). Opracowanie to stanowi, jak dotychczas, najpełniejsze kompendium wiedzy o badaniach geograficznych osadnictwa w XX w., prowadzonych na terenie Polski. W podsumowaniu tomu 2. zamieszczono interesujący tekst Z. Rykla (1994), który uznać należy za odrębny artykuł przeglądowo-metodologiczny.

Kontynuacją tematyki zamieszczonej w wymienionych publikacjach była praca zbiorowa (Liszewski, Maik 2005), a także artykuł tych samych autorów (Liszewski, Maik 2008).

Obok prac monitorujących dorobek badawczy całej geografii osadnictwa ukazują się również w Polsce podsumowania wyników badań niektórych problemów czy kierunków badań. Przykładowo można tu wymienić prace podsumowujące badanie małych miast (Matczak 2007; Kwiatek-Sołtys 2011; Kobojek, Marszał 2014) lub analizujące trwające kilkanaście lat badania łódzkich geografów nad ośrodkami lokalnymi i metodami ich badań (Liszewski 1993). 
Rozwój badań geograficznych nad osadnictwem w Polsce...

Podsumowań cząstkowych jest $\mathrm{w}$ dorobku polskich geografów znacznie więcej, bowiem tradycyjnie autorzy niemal każdej pracy przygotowywanej na stopień naukowy (prace doktorskie i habilitacyjne) dokonują gruntownego przeglądu literatury w zakresie podejmowanego problemu badawczego.

\section{Podręczniki}

Obok prac przeglądowych, dobrym źródłem wiedzy o dorobku, a zwłaszcza kierunkach badań geografów nad osadnictwem, są podręczniki akademickie i wydawnictwa naukowe typu encyklopedycznego.

Pierwszym podręcznikiem akademickim, zatytułowanym Geografia osadnictwa. Zarys problematyki, jest kilkakrotnie wznawiana praca M. Kiełczewskiej-Zaleskiej (1969). Treść tego podręcznika odpowiadała zakresowi tematycznemu wykładu kierunkowego na studiach geograficznych w polskich wyższych uczelniach. Przez wiele lat przedmiot ten nosił nazwę geografia osadnictwa i zaludnienia. Wymieniony podręcznik Kiełczewskiej-Zaleskiej był uzupełniany publikacją Geografia ludności (Kosiński 1967).

Treść dotyczącą geografii osadnictwa ujęto w książce M. Kiełczewskiej-Zaleskiej w trzy duże części: Wiadomości ogólne (geografia osadnictwa jako nauka, czynniki kształtujące osadnictwo); Osiedla pierwotne $i$ wsie (osadnictwo pierwotne, wieś i rolnictwo ustabilizowane, osiedla o charakterze wiejsko-miejskim); Podstawowe pojęcia z geografii miast. Obszerna część ostatnia wypełnia połowę podręcznika. Autorka w sposób sygnalny omawia tu m.in.: definicję miasta, funkcje, strukturę wewnętrzną, fizjonomię, sieć miast oraz miasta w regionie. Część tę kończy podrozdział o rozwoju procesów urbanizacji, rozmieszczenia miast oraz ich zróżnicowania regionalnego. Treść tego podręcznika dobrze oddaje stan wiedzy geografów, ale również ich zainteresowania badawcze w latach 60. XX w.

Dynamiczny rozwój badań naukowych nad geografią osadnictwa w następnych dziesięcioleciach nie przekładał się na publikację podręczników akademickich. Dopiero na początku lat 90. ukazał się skrypt wydany przez Uniwersytet Mikołaja Kopernika w Toruniu autorstwa W. Maika (1992) pt. Podstawy geografii miast. Zgodnie z tytułem, treść tej pracy była ograniczona tylko do problematyki miejskiej i została ujęta w sześciu rozdziałach: wprowadzenie, powstanie i rozwój miast (proces urbanizacji), podstawy analizy funkcjonalnej miast, struktura przestrzenna miasta, relacje między miastem i otoczeniem oraz systemy miast. Skrypt ten, w porównaniu z omawianym wcześniej podręcznikiem, zawiera nową problematykę badawcza, podjętą przez geografów w latach 70. i 80. XX w. 
Po upływie czterdziestu lat od wydania przez PWN podręcznika M. Kiełczewskiej-Zaleskiej oficyna ta opublikowała Geografię osadnictwa D. Szymańskiej (2009). Podręcznik ten liczy blisko 400 stron, jest bogato ilustrowany i zawiera składający się z kilkuset pozycji spis literatury. Układ niewiele się różni od pracy M. Kiełczewskiej-Zaleskiej, natomiast znacznie bogatsza jest treść, zostały ponadto zmienione proporcje. Część piąta pracy poświęcona miastu i osadnictwu miejskiemu liczy prawie 160 stron. Pracę kończy rozdział zatytułowany Osadnictwo w globalizującym się świecie. Podręcznik ten prezentuje stan wiedzy geograficznej o osadnictwie na początku XXI w., a bogata literatura (z dużym udziałem prac autorów zagranicznych) oraz aneks zawierający definicje miast w różnych krajach świata, umożliwia podjęcie solidnych studiów nad problematyką osadniczą.

Omawiając podręczniki z zakresu geografii osadnictwa, należy wspomnieć 19. tom Wielkiej encyklopedii geografii świata pt. Osadnictwo autorstwa S. Liszewskiego i W. Maika (2000). Treścią tego tomu, na który składa się 350 stron tekstu oraz kilkaset map, rycin i fotografii, są różne formy osad ludzkich - od najprostszych, zdeterminowanych warunkami środowiska przyrodniczego, po wielkie skupiska miejskie. Praca składa się z czterech części. Są to: Wprowadzenie (część teoretyczna), Osadnictwo wiejskie, 34 Osadnictwo miejskie oraz Systemy osadnicze. Na końcu zamieszczono spis najważniejszych pozycji literatury polskiej i zagranicznej. Tom ten przez pewien czas był polecany studentom jako podręcznik akademicki.

Oprócz prac, których tytuły jednoznacznie określają geograficzną zawartość treści, ukazały się również podręczniki akademickie autorstwa geografów, w których prezentowane są nowe pola badawcze i możliwości wykorzystania wiedzy geograficznej, zarówno do badań naukowych, jak i w działalności aplikacyjnej. Należy tu wymienić dwa wydania podręcznika akademickiego pt. Geografia urbanistyczna pod red. S. Liszewskiego (2008, 2012), którego treść prezentuje wkład geografów do planowania urbanistycznego. Próbą podsumowania badań nad procesami urbanizacji w skali świata jest podręcznik D. Szymańskiej (2008) pt. Urbanizacja na świecie. Autorka koncentruje swoją uwagę na wielkich miastach oraz negatywnych i pozytywnych konsekwencjach tego ogarniającego cały świat procesu.

Dla pełnej informacji trzeba tu również wymienić podręczniki pozwalające na pogłębienie wiedzy z geografii osadnictwa w zakresie pól badawczych podejmowanych przez geografów, takich jak geografia społeczna miasta (Węcławowicz 2003, 2007) lub powrotu do uprawianej już wcześniej przez nich fizjografii urbanistycznej (Szponar 2003). Oryginalnym wkładem geografów $\mathrm{w}$ problematykę urbanistyczną jest obszerny podręcznik J. Słodczyka (2012) pt. Historia planowania i budowy miast. 
Wymienione podręczniki nie wyczerpują zapewne listy tego typu prac, które ukazały się w Polsce w ciągu ostatnich 100 lat, pokazują jednak główne nurty badawcze, podejmowane przez geografów. Rozwój badań nad geografią osadnictwa w Polsce w sposób usystematyzowany i całościowy został również przedstawiony w rozdziale autorstwa S. Liszewskiego (2008), zamieszczonym w książce Historia geografii polskiej.

\section{Konferencje naukowe}

Tradycyjnie miejscem prezentacji wyników badań lub dyskusji metodologicznych są konferencje naukowe. Organizują je również geografowie zajmujący się osadnictwem lub uczestniczą oni w konferencjach geografów innych specjalności, a także reprezentantów innych nauk. Konferencji takich tylko w Polsce odbywa się kilka w ciaggu roku, co pokazuje skalę tej formy aktywności, ale jednocześnie trudności w dotarciu do nich i wykorzystaniu ich dorobku w prowadzonej $w$ tej pracy analizie. Uwzględniono referaty, opublikowane $\mathrm{w}$ formie artykułów, które pochodzą $\mathrm{z}$ dwóch systematycznie odbywających się konferencji. Pierwszą z nich jest Konwersatorium wiedzy o mieście, organizowane przez Instytut Geografii Miast i Turyzmu Uniwersytetu Łódzkiego od roku 1988. Organizatorem drugiej, cyklicznej konferencji poświęconej problematyce miejskiej jest Katedra Geografii Ekonomicznej i Gospodarki Przestrzennej Uniwersytetu Opolskiego. Konferencja ta jest organizowana od 2000 r., a związane z nią wydawnictwo pt. „Studia Miejskie” ukazuje się od 2010 r. (w roku 2015 ukazał się 13. numer).

Korzenie „Konwersatorium Wiedzy o Mieście” sięgają 1965 r., kiedy ówczesny Kierownik Katedry Geografii Ekonomicznej UŁ, prof. Ludwik Straszewicz, zorganizował pierwszą , regionalną" konferencję poświęconą „migracjom i dojazdom do pracy". Konferencje te, organizowane zawsze w styczniu, rozrosły się do spotkań o charakterze międzynarodowym i przyjęły nieformalną nazwę „łódzkie konferencje styczniowe”. Były one organizowane do śmierci profesora, czyli do 1987 r. (razem 19 spotkań).

Począwszy od $1988 \mathrm{r}$. zmieniono termin i nazwę tych spotkań oraz doprecyzowano tematykę. Konwersatoria wiedzy o mieście odbywają się zawsze w kwietniu i każde z nich ma konkretny temat dotyczący miasta. Organizatorem Konwersatorium zostały Zakład, a później Katedra i Instytut Geografii Miast i Turyzmu UŁ.

Prezentowane podczas obrad referaty i postery, po pozytywnym przejściu procedury recenzyjnej, zamieszczane są w kolejnych numerach (tomach) „Konwersatorium”. Do lipca 2015 r. odbyło się 27 spotkań, wydano również 27 tomów periodyku. Na okładce każdego tomu podany jest konkretny tytuł spotkania. 


\section{Inne źródła informacji}

Pragnąc zgromadzić w miarę pełny materiał źródłowy, dotyczący dorobku polskiej geografii osadnictwa, sięgnięto również do wydawnictw i czasopism oraz innych drukowanych opracowań. Dokonano kwerendy w czasopismach: „Przegląd Geograficzny", ,"Geographia Polonica”, ,"Czasopismo Geograficzne”, "Studia KPZK PAN", "Biuletyn KPZK PAN”, „Prace Geograficzne” IGiPZ PAN, wydawnictwa geograficzne kilku uniwersytetów, a także sięgnięto do wydawnictwa pt. Podstawowe idee $i$ koncepcje w geografii, redagowanego przez W. Maika, K. Rembowską i A. Suliborskiego (8 tomów).

Najcenniejszym materiałem pokazującym rozwój i aktualność badań $\mathrm{w}$ geografii osadnictwa sa, zdaniem autora, prace wykonane na stopnie naukowe: doktora (w mniejszym stopniu) i doktora habilitowanego. W ciągu ostatnich pięciu lat nastąpił w Polsce "wysyp” habilitacji (także geograficznych), do których dostęp jest jednak dość ograniczony. Autor wykorzystał w tym opracowaniu dostępne prace, które powstały w ośrodkach: łódzkim, krakowskim, warszawskim, śląskim i lubelskim.

Przedstawione $\mathrm{w}$ tym rozdziale źródła i materiały autor gromadził od dłuższego czasu, jest ich bowiem bardzo dużo, a ich klasyfikacja wyma36 ga zapoznania się z treścią. W dalszej części pracy zostaną wykorzystane tylko niektóre - zdaniem autora najważniejsze - prace, ale przedstawiony tu zasób materiałów i źródeł może być pomocny innym badaczom pragnącym poznać i ocenić dorobek w zakresie badań osadnictwa w Polsce.

\section{Główne kierunki badań polskich geografów nad osadnictwem}

Wykorzystując omówione wcześniej źródła i materiały, autor podejmuje próbę zaprezentowania głównych, jego zdaniem, kierunków badań polskich geografów nad osadnictwem, przyjmując podział całego stulecia na trzy nierówne okresy, wynikające z współczesnych dziejów Polski. Są to: okres pierwszy, do 1939 r. (II RP); okres drugi, lata 1945-1989 (PRL) i okres trzeci, po 1990 r. (III RP). Okresy te różnią się nie tylko długością trwania ale również ilością ośrodków geograficznych w których prowadzono badania naukowe. W okresie II RP działało w Polsce pięć uniwersytetów w których były katedry lub instytuty geografii (Kraków, Lwów, Warszawa, Wilno i Poznań). W latach 70. XX w., jednostki naukowo-dydaktyczne geografii działały na 19 wyższych uczelniach oraz w Instytucie Geografii i Przestrzennego Zagospodarowania PAN. Taka sama liczba jednostek geograficznych była w Polsce w 2015 r. 
Rozwój badań geograficznych nad osadnictwem w Polsce...

W każdym z wymienionych okresów autor, korzystając z prac publikowanych, wyróżnił główne kierunki prowadzonych przez geografów badań nad osadnictwem, dokumentując je wybranymi przez siebie pracami. Zarówno nazwy wyróżnionych dziewięciu kierunków badań, jak i wybrane do ich ilustracji prace mają charakter autorski (subiektywny).

\section{Wpływ środowiska geograficznego na powstanie i rozwój osadnictwa}

Powstanie geografii jako nauki nowożytnej łączy się z nazwiskami Alexandra Humboldta (1769-1859) i Karla Rittera (1779-1859). Twórcy tej nauki starali się przekształcić geografię z wiedzy opisowej w naukę problemowa, która ma wyjaśnić przyczyny i skutki badanych zjawisk, a także poszukiwać związków między elementami środowiska przyrodniczego i człowiekiem.

Późniejszy podział geografii na fizyczną (środowisko przyrodnicze) i antropogeografię (geografia człowieka) nie zwalniał badaczy od poszukiwania związków między przyrodą i działalnością człowieka. Związki te, a nawet zależności (determinizm), w odniesieniu do badań osadnictwa najwyraźniej są dostrzegalne $\mathrm{w}$ analizie przyczyn powstania, położenia i działalności (rozwoju) jednostek osadniczych. Rozwój techniki w określonym stopniu uniezależnia człowieka od środowiska przyrodniczego, ale - jak pokazują współczesne anomalie klimatyczne czy geologiczne zależność ta wciąż istnieje i daje znać o sobie, czasami w sposób dramatyczny. Koniecznością chwili jest również ochrona i właściwe gospodarowanie zasobami przyrody, co znajduje odbicie w rozwoju współczesnego osadnictwa.

Wśród prac, które powstały w pierwszym z omawianych okresów (lata 1918-1939) znaleźć można opracowania, w których geografowie zajmują się badaniami bezpośrednich związków i zależności między środowiskiem przyrodniczym a osadami ludzkimi. Przykładowo tylko można tu wskazać prace S. Leszczyckiego (1932) dotyczące osadnictwa w Beskidzie Wyspowym i Jana Dylika (1939), który analizował położenie geograficzne Tumu i Łęczycy w kontekście konsekwencji płynących z czynników przyrodniczych.

Również w czasach PRL (okres II) część geografów podjęła studia dotyczące zależności między środowiskiem przyrodniczym, historia, komunikacją i rozwojem gospodarczym a powstaniem i rozwojem osad ludzkich (zarówno wsi, jak i miast). Wymienić tu należy m.in. prace M. Janiszewskiego $(1973,1991)$, który analizował położenie geograficzne polskich miast i M. Kiełczewskiej-Zaleskiej $(1947,1953)$, która przeprowadziła szczegółowe studia nt. położenia Torunia i Poznania. Generalnie jednak 
w tym okresie starano się $\mathrm{w}$ badaniach geograficznych pomijać tę problematykę lub ją marginalizować.

W trzecim z przyjętych okresów (po 1989 r. - III RP) geografowie w Polsce praktycznie zaprzestali zajmować się tą nie tylko bardzo ważną (rozwój zrównoważony), lecz także potrzebną problematyką badawczą. Wydaje się, że wynika to z braku odpowiednich umiejętności i ogólnogeograficznej wiedzy współczesnych absolwentów geografii, a co gorsze z błędnego przekonania o małej przydatności takich badań. Jedną z niewielu prac, które powstały w tym okresie jest artykuł S. Liszewskiego (1995) o geografii miast nadrzecznych.

\section{Osadnictwo wiejskie}

Zainteresowanie geografów osadnictwem wiejskim ze względu na jego silny związek ze środowiskiem przyrodniczym trwa od dawna i obejmuje analizy: położenia geograficznego i warunków przyrodniczych, fizjonomii, budowy morfologicznej i kształtów wsi, a także sieci osadniczej, funkcji oraz szeroko rozumianych przekształceń. Zakres tematyczny badań nad osadnictwem wiejskim w ostatnim okresie (III RP) uległ wyraźnym zmianom.

Pierwsze badania nad osadnictwem wiejskim były prowadzone w ośrodkach krakowskim i lwowskim, w ścisłej symbiozie z historykami (Szulc 1994; Rajman 1994). W okresie II RP na szeroką skalę studia te zainicjował S. Pawłowski w Poznaniu. Prowadzono tu badania morfologiczne nad osadnictwem wiejskim Wielkopolski, a potem Pomorza Gdańskiego (Kiełczewska 1931, 1956). W ośrodku poznańskim osadnictwem wiejskim zajmowali się: Pawłowski, Kiełczewska, Świderski, a także Dylik.

Znaczny wkład do rozwoju badań nad osadnictwem wiejskim wniósł również B. Zaborski (1926), który opublikował pracę pt. O kształtach wsi $w$ Polsce $i$ ich rozmieszczeniu. Zaproponowane przez tego autora typy kształtów wsi weszły do literatury przedmiotu. Autor tej pracy był związany najpierw z Uniwersytetem Jagiellońskim, a później Warszawskim.

Zakończenie II wojny światowej przyniosło Polsce nie tylko zmiany terytorialne, lecz także ustrojowe. Te ostatnie dotyczyły m.in. polityki rolnej (powstanie PGR i Spółdzielni Produkcyjnych) i miały duży wpływ na osadnictwo wiejskie.

Geografowie kontynuowali w tym okresie badania historyczno-morfologiczne. Dotyczy to zwłaszcza trzech ośrodków akademickich: Torunia (M. Kiełczewska-Zaleska, E. Kwiatkowska), Wrocławia (S. Golachowski, H. Szulc, J. Tkocz) i Krakowa (M. Dobrowolska, A. Prochownikowa). Powstające $\mathrm{w}$ tym okresie prace, obok badań empirycznych, miały także charakter podsumowujący dotychczasowy dorobek badawczy (Kieł- 
czewska-Zaleska 1964; Szulc 1995; Tkocz 1971). Wyjątkiem były artykuły S. Golachowskiego (1964) i M. Kiełczewskiej-Zaleskiej (1963), w których sformułowano nowe kierunki i programy badań nad morfologią osiedli wiejskich.

Ukoronowaniem badań historyczno-morfologicznych wsi jest Atlas historyczny wsi w Polsce autorstwa H. Szulc (2002). Praktycznie po śmierci prof. H. Szulc przerwano badania geograficzno-historyczne wsi w Polsce.

Równolegle $\mathrm{z}$ badaniami historycznymi geografowie prowadzili w tym okresie badania demograficzne i społeczno-ekonomiczne na obszarach wsi. Ich wyniki omówił J. Rajman (1994). Podsumowaniem badań prowadzonych przez geografów w okresie II (PRL) jest praca autorstwa J. Tkocza (1998) pt. Organizacja przestrzenna wsi w Polsce.

W przeglądzie tym świadomie pominięto prace dotyczące szeroko rozumianego użytkowania rolniczego ziemi i gospodarki rolnej, którymi w Polsce zajmowała się odrębna subdyscyplina - geografia rolnictwa. Promotorem tych badań w skali międzynarodowej był prof. Jerzy Kostrowicki.

Wyczerpanie się tematyki badań historycznych nad osadnictwem wiejskim, a także dynamiczny rozwój geografii społecznej oraz przemiany polityczno-gospodarcze, jakie objęły Polskę po 1989 r., dały asumpt do prezentacji nowych koncepcji badawczych, sygnalizowanych w literaturze jako geografia wsi (Bański 2006; Wójcik 2012). W koncepcji autorstwa M. Wójcika wieś jest rozumiana w sensie largo, czyli szeroko: jako cały obszar wiejski. Stąd geografia wsi, wg tego autora, to dyscyplina badająca wszelkie przejawy działalności człowieka, zachodzące na obszarach wiejskich.

W cytowanej pracy czytamy: „Wydaje się, że pewnym rozwiazaniem może być przyjęcie szerokiej definicji geografii wsi, której przedmiotem badań jest życie na obszarach wiejskich. W ten sposób rozumiana geografia wsi swój zakres poznawczy wywodzi wprost z regionalnej tradycji studiów geograficznych" (Wójcik 2012: 220).

Kończąc prezentację badań nad osadnictwem wiejskim, należy zwrócić uwagę na zmienność tematyki badań geograficznych w tym zakresie. Potwierdza ona przydatność analizy geograficznej do rozwiązywania problemów przestrzennych, występujących w różnych warunkach przyrodniczych i różnych systemach społeczno-gospodarczych.

\section{Studia geograficzno-historyczne miast}

Geograficzne badania miast zainicjowano w latach 20. XX w. na Uniwersytecie Jagiellońskim. Ich inicjatorem był L. Sawicki, a założenia programu badań opublikował W. Ormicki (1932). Koncepcja badania miasta wykorzystywała tzw. plan krajobrazowy, który był podstawą analizy, 
zarówno budowy morfologicznej, jak i zróżnicowania funkcjonalnego (użytkowanie ziemi) i fizjonomii, a także gospodarki. W pierwszym okresie (II RP) powstały m.in. prace nt. Nowego Sącza (Kubijowicz), Krakowa (Mrazkówna), Łodzi (Kossmann), a zwłaszcza wzorcowa dla tego okresu praca na temat Tarnowa autorstwa Z. Simchego (1930) i praca habilitacyjna W. Rewieńskiej z Uniwersytetu Wileńskiego.

Ten krótki, trwający zaledwie niecałe dwadzieścia lat, okres międzywojenny, ma bardzo duże znaczenie dla rozwoju w Polsce badań osadnictwa, prowadzonych przez geografów. To właśnie wtedy sformułowano podstawy metodologiczne badań geograficznych, zarówno wsi, jak i miast i przetestowano je na kilku przykładach.

W okresie PRL geograficzno-historyczne badania miast zainicjował K. Dziewoński $(1947,1962)$, publikując artykuły o przeobrażeniach osadnictwa miejskiego w Polsce oraz typologii morfologicznej miast. Badania empiryczne nad tym problemem, jak podają M. Koter i M. Kulesza (1994), podjęto wtedy w dwóch ośrodkach geograficznych, wpierw we Wrocławiu, a po paru latach w Łodzi.

Pionierem badań geograficzno-historycznych miast we Wrocławiu był S. Golachowski (1969), który dokonał wnikliwej analizy planów wybranych miast śląskich (Opole, Gliwice, Bytom, Racibórz). Badania te kontynuowała B. Miszewska (1966, 1971), która wykonała analizy morfologiczne Wrocławia i Opola. Przy analizie rozwoju morfologicznego tych miast Miszewska zbadała, po raz pierwszy w Polsce, tzw. cykl rozwoju działki miejskiej, wykorzystując metodę M. R. G. Conzena. Metodę tę zastosowali również Koter i Wiktorowska (1976) przy analizie przemian morfologicznych śródmieścia Łodzi. Dalszym etapem badań geograficzno-historycznych miast była analiza struktury przestrzennej, którą m.in. dla Radomia wykonał S. Witkowski (1967), naukowo związany w tym okresie z ośrodkiem wrocławskim.

Jak już wcześniej powiedziano, drugim ośrodkiem badań geograficzno-historycznych miast w Polsce była w tym okresie Łódź. Badania M. Kotera $(1969,1979)$ koncentrowały się pierwotnie wokół wyjaśnienia genezy układów Łodzi przemysłowej, a następnie struktury morfogenetycznej tego miasta. Koter (1994) jest również autorem pracy o charakterze teoretycznym, która nosi tytuł Od fizjonomii do morfogenezy i morfologii porównawczej miasta. Podstawowe zagadnienia teoretyczne morfologii miast.

W ostatnim omawianym okresie (III RP) intensywność badań geograficzno-historycznych miast znacznie zmalała, choć interesujący jest fakt, że nowe prace powstają głównie w ośrodkach geograficznych, w których od lat prowadzono badania morfologiczne (ciągłość tematyczna).

Z ośrodka łódzkiego wywodzą się dwie prace (przedwcześnie zmarłego) M. Kuleszy (2001, 2011), które dotyczą morfologii i morfogenezy 
miast, głównie Polski środkowej oraz oryginalna praca J. Kotlickiej (2008), w której wykorzystano koncepcję przekształceń morfologicznych miasta do analizy przemian terenów przemysłowych Łodzi.

Z Uniwersytetu Wrocławskiego pochodzi praca habilitacyjna R. Szmytkie (2014), mająca charakter metodyczny i dotycząca metod analizy morfologii i fizjonomii jednostek osadniczych.

Na zakończenie oceny tego nurtu badawczego w polskiej geografii osadnictwa należy odnotować ukazanie się artykułu M. Kotera i M. Kuleszy (2007), będącego omówieniem stanu i tendencji rozwoju badań nad morfologią miast w skali międzynarodowej. Autorzy wykorzystali sprawozdanie z działalności International Seminar on Urban Form i wydawane przez to stowarzyszenie czasopismo „Urban Morphology". Informacja ta może być zachętą do włączenia się do badań nad morfologią miast młodych polskich geografów o zainteresowaniach historycznych.

\section{Studia nad małymi i średnimi miastami}

Zainteresowanie geografów małymi miastami jest widoczne w całym omawianym tu okresie 100 lat, o czym świadczą liczne prace prezentujące wyniki badań indywidualnych autorów i zespołów badawczych. Ta ciągłość zainteresowań małymi miastami jako obiektem badań geograficznych wynika zapewne stąd, że jest to najliczniejsza grupa miast w naszym kraju i w różnych okresach naszej historii, zarówno politycznej, jak i gospodarczej - przystosowując się do nowych sytuacji - zmieniały one swoje funkcje. Dlatego można powiedzieć, że „problem małych miast” w sensie badawczym jest wciąż aktualny.

W pierwszym okresie poddanym rozważaniom (II RP) dominowały $\mathrm{w}$ tych badaniach podejście antropogeograficzne i ujęcie monograficzne, czego przykładem mogą być prace W. Rewieńskiej (1934, 1934a) o Brasławiu i Berezie Kartuskiej oraz J. Tochtermana (1935) o Trokach.

Konsekwencją II wojny światowej było m.in. ogromne wyludnienie małych miast (wymordowano ludność żydowską), a w następstwie zmian ustrojowych nastąpił upadek prywatnej działalności gospodarczej (sklepy, rzemiosło, drobna wytwórczość), który doprowadził do degradacji gospodarczej małych miast i spowodował migrację ludności do ośrodków przemysłowych i dużych miast.

Próbą dokładnego rozeznania sytuacji, a zwłaszcza poszukiwania możliwości aktywizacji gospodarczej małych miast, był podjęty przez geografów ogólnopolski program badawczy. Koordynacją tych badań zajmował się Instytut Geografii PAN, a uczestniczyły w nim wszystkie ośrodki geograficzne $\mathrm{w}$ Polsce. W konsekwencji przebadano kilkadziesiąt miast - wyniki tych badań zostały opublikowane w pracy zbiorowej 
pod redakcją K. Dziewońskiego i in. (1957). Trudno dziś stwierdzić, czy i w jakim stopniu wyniki tych badań zostały wykorzystane w praktyce gospodarczej, ale niewątpliwie było to największe, zorganizowane przez geografów, badanie małych miast w Polsce.

Innym bodźcem skłaniającym do ponownego zajęcia się małymi miastami była dyskusja naukowa wywołana w latach 60. XX w. publikacjami M. Chilczuka, które nawiązywały do znanej wcześniej teorii ośrodków centralnych W. Christallera. Chilczuk określił w swoich pracach hierarchię ośrodków, uwzględniając wyposażenie wsi i małych miast, głównie w urzędy oraz instytucje usługowe, co w aktualnej sytuacji w Polsce budziło wątpliwości. Pragnąc włączyć się do tej dyskusji, geografowie ówczesnej Katedry Geografii Ekonomicznej UŁ podjęli badania nad małymi miastami w województwach opolskim i łódzkim, których celem było wyznaczenie stref ich wpływów i na tej podstawie określenie stopnia lokalności czy centralności badanych miast. Podsumowanie tych oryginalnych badań zostało opublikowane przez S. Liszewskiego (1993).

Okres III RP i powrót do samorządności gmin, których siedzibami są głównie małe miasta, rozpoczął renesans tych jednostek osadniczych i skłonił geografów do ponownego zainteresowania się nimi. Różnorodność podejmowanych badań dobrze ilustruje artykuł przeglądowy E. Ko-

42 bojek i T. Marszała (2014) oraz prace A. Kwiatek-Sołtys (2011), a także praca zbiorowa pod red. B. Bartosiewicza i T. Marszała (2011). Pewnym nawiązaniem do poprzednio omówionych badań jest praca pod red. K. Heffnera i T. Marszała (2005) na temat ośrodków lokalnych w strefach oddziaływania wielkich miast.

Stosunkowo nowym problemem badawczym w polskiej geografii osadnictwa są miasta średniej wielkości (50-100 tys. mieszkańców). Pierwsze opracowanie takiego miasta, wykorzystujące studia terenowe, wykonane przez geografów UJ oraz Instytutu Geografii PAN, zostało opublikowane jako praca zbiorowa pt. Studia z geografii średnich miast w Polsce. Problematyka Tarnowa (1971). Oryginalność tej pracy - obok zastosowania nowych metod badań terenowych i opracowania zebranego materiału polega na tym, że autorzy starali się porównywać rezultaty swoich badań z opublikowaną przez Z. Simchego (1930) 40 lat wcześniej, cytowaną już w tym opracowaniu, pracą pt. Tarnów i jego okolice, chcieli też uchwycić kierunki i skalę zachodzących zmian.

Zainteresowanie miastami średnimi wzrosło w Polsce w latach 70., co było związane z nowym podziałem administracyjnym Polski i utworzeniem nowych województw, których siedzibami zostały niektóre miasta średnie. $Z$ tego okresu pochodzą bardzo dojrzała metodycznie praca A. Werwickiego (1973) oraz opracowanie zbiorowe monografii geograficznej Sieradza (1982). Interesujące są również prace R. Matykowskiego 
(1990) o Gnieźnie i E. Rydza (1990) o funkcji Koszalina i Słupska w regionalnej sieci osadniczej.

Na podkreślenie zasługuje także fakt, że podczas badania miast średnich geografowie zastosowali nowe metody badań terenowych i prezentacji uzyskanych wyników. Ta skala miasta okazała się dla geografów bardzo dobrym poligonem badawczym.

O ile geograficzne badania małych miast koncentrowały się w Polsce wokół ich podstaw gospodarczych oraz funkcji ośrodków lokalnych bądź centralnych, o tyle badania miast średnich dotyczyły głównie ich struktur wewnętrznych i roli w tworzeniu regionalnych systemów osadniczych (Runge 2013).

\section{Wielkie skupiska miejskie}

Rozwój zainteresowania polskich geografów wielkimi skupiskami miejskimi następował stopniowo, $\mathrm{w}$ miarę ich powstawania i rozwoju w naszym kraju. W okresie II RP praktycznie nie prowadzono w Polsce badań nad tą formą osadnicza, a ukazujące się niezbyt liczne prace miały charakter informacyjny lub krajoznawczy. L. Sawicki (1914) opublikował artykuł na temat Warszawy w języku niemieckim, o Lwowie pisał kilkakrotnie W. Kaczorowski, o Chicago A. Zglinnicka, a interesujący szkic geograficzny o najstarszym Paryżu opracowała W. Rewieńska (1930). Badania nad wielkimi miastami rozpoczęli polscy geografowie na początku lat 70 . XX w., choć już wcześniej ukazała się interesująca praca (Iwanicka-Lyra 1969) na temat delimitacji aglomeracji wielkomiejskich.

Pierwsze dyskusje koncentrowały się wokół zakresu pojęciowego wielkiego miasta, jego form przestrzennych i funkcji oraz metod delimitacji. Za pracę, która dała podstawę do poważnych dyskusji i dalszych badań dość zgodnie uznaje się opracowanie autorstwa S. Leszczyckiego, E. Eberhardta i S. Heřmana (1971). Dotyczyła ona delimitacji aglomeracji miejsko-przemysłowych w Polsce w 1966 r. i prognozy ich rozwoju do roku 2000. W tym samym okresie delimitacją wielkomiejskich układów osadniczych zajmował się również Z. Gontarski (1973). Wśród wielu ukazujących się w latach 70. prac poświęconych zwykle konkretnym aglomeracjom należy wymienić publikację Z. Rykla (1978), który podjął badania nad miejscem aglomeracji w przestrzeni społeczno-gospodarczej Polski.

Dyskusja nad aglomeracjami miejskimi wyłoniła kilka problemów szczegółowych. Jednym z nich była strefa podmiejska, tworząca otoczkę skupisk miejskich. Ukazało się wiele publikacji omawiających ten temat, z których wymienię tylko pozycje problemowe lub przekrojowe - L. Straszewicza (1954, 1985), K. Dziewońskiego (1987), S. Liszewskiego (1987), J. Jakóbczyk-Gryszkiewicz (1998), a ostatnio S. Staszewskiej (2013). 
Innym dyskutowanym problemem były relacje między aglomeracją miejską a zespołem miejskim (Jakóbczyk-Gryszkiewicz 1982). Interesującą genezę aglomeracji miast na obszarze Polski przedstawił R. Krzysztofik (2014) po przeprowadzeniu solidnych badań historycznych. Dalszy etap badań geografów nad wielkimi skupiskami miejskimi był związany z regionami miejskimi (Korcelli 1981, Jakóbczyk-Gryszkiewicz [red.] 2011).

W trzecim z badanych okresów (III RP) badania geografów koncentrują się na metropoliach miejskich, które uznaje się za najwyższy stopień zorganizowania wielkich skupisk miejskich.

Pierwszą poważniejszą pracę na temat metropolii i funkcji metropolitalnych opublikował P. Korcelli (1998), choć należy wspomnieć, że już w latach 70. ukazała się praca Z. Gontarskiego (1972) zatytułowana Delimitacja obszarów metropolitalnych w Polsce.

Problematyka metropolii $\mathrm{w}$ ostatnich latach stała się przedmiotem wielu prac, wśród których wymienię tu tylko kilka najbardziej charakterystycznych ze względu na tematykę lub kompleksowość ujęcia. Są to prace: B. Jałowieckiego (1999), A. Wolaniuk (1997), pod redakcją I. Jażdżewskiej (2002), E. Korcelli-Olejniczak (2004), T. Markowskiego, T. Marszała (2006), T. Czyż (2009) oraz S. Liszewskiego (2010). Wydaje się, że nowy etap badań nad metropoliami otwiera praca E. Korcelli-Olejniczak (2012) nt. regionu metropolitalnego.

Kończąc przegląd najważniejszych, zdaniem autora, problemów badawczych podejmowanych przez polskich geografów zajmujących się wielkimi skupiskami miejskimi, pragnę tu podkreślić rolę, jaką w rozwoju tych badań odegrał zmarły w 1987 r. Ludwik Straszewicz. Profesor jako jeden z pierwszych geografów w Polsce podjął badania nad strefami podmiejskimi dużych miast, publikując w latach 50. kilka artykułów poświęconych strefie podmiejskiej Łodzi (Straszewicz 1954). Do tematu wracał kilkakrotnie w swoich badaniach, publikując ostatni artykuł w 1985 r. Strefa podmiejska Łodzi i jej przemiany była poligonem badawczym, pozwalającym Profesorowi śledzić procesy przekształcania się w aglomerację miejską obszarów rolniczych, jakimi na początku lat 50 . były okolice Łodzi i miast przemysłowych.

Jeszcze większy był wkład prof. Straszewicza w poznanie genezy, budowy morfologicznej oraz rozwoju przestrzennego, gospodarczego i demograficznego wielkich miast Europy. Profesor opublikował w najważniejszym przez lata w Polsce czasopiśmie naukowym, jakim był „Przegląd Geograficzny", siedem artykułów dotyczących wielkich miast Europy (Paryż, Londyn, Moskwa, Berlin, Rzym, Madryt i Lizbona). Pierwszy z nich ukazał się w 1963 r. i był poświęcony Paryżowi, ostatnie dwa, poświęcone Madrytowi i Lizbonie, ukazały się w $1981 \mathrm{r}$. W tytułach swoich artykułów autor odpowiednio klasyfikował miasto, zaznaczając, czy jest 
to aglomeracja, czy metropolia. W znacznie rozszerzonej wersji opublikował Straszewicz $(1972,1974)$ monografię czterech miast: Londynu, Moskwy, Paryża i Rzymu pod wspólnym tytułem: Wielkie stolice Europy.

Jako obserwator powstawania tych prac mogę stwierdzić, jak gromadzony był materiał źródłowy, niezbędny do przeprowadzenia analiz. Profesor wpierw wykonywał solidną kwerendę literatury, materiałów statystycznych i kartograficznych, które można było znaleźć w Polsce, a następnie powtarzał to w każdym opracowywanym mieście. Ostateczne przygotowanie pracy poprzedzały solidne studia terenowe $\mathrm{z}$ udziałem miejscowych geografów i urbanistów (pobyt trwał zwykle kilka tygodni).

Prace Profesora na temat miast-stolic Europy są do dzisiaj wykorzystywane przez osoby, które chcą poznać genezę i drogi rozwoju tych dzisiaj już wielkich skupisk miejskich. Można wyrazić żal, że geografowie nie kontynuują tej serii opracowań, które - niezależnie od warstwy poznawczo-faktograficznej - pokazują zróżnicowanie form i przekształceń miast, na skutek generalizacji zaliczanych do aglomeracji lub metropolii, co zaciera ich niewątpliwą indywidualność.

\section{Funkcje i struktury funkcjonalne miast}

Bardzo ważne miejsce $\mathrm{w}$ badaniach geograficznych zajmują prace poświęcone funkcji i strukturze funkcjonalnej miast. Badania te dotyczą podstaw gospodarczych miast, nazywanych bazą ekonomiczną oraz pozycji miasta w sieci osadniczej (Jaroszewska, Maik 1994). Zainteresowanie tematyką funkcji i typami funkcjonalnymi miast zasygnalizował w okresie II RP Walenty Winid (1937), ale rozwinęły się one dopiero po II wojnie światowej, co było związane z odbudową powojenną miast i przebudową sieci osadniczej Polski.

W pierwszych pracach powstałych w okresie PRL autorzy próbowali określić miasto, analizując strukturę zatrudnienia jego mieszkańców wg zawodów (Wejchert 1947; Kostrowicki 1952; Kosiński 1958; Wróbel 1970). Pewnego przełomu w tych badaniach dokonała praca M. Chilczuka (1963), który próbował połączyć podejście ekonomiczne i przestrzenne. Największy jest jednak wkład do omawianych badań K. Dziewońskiego (1967) i M. Jerczyńskiego (1971, 1973, 1977). Dziewoński przedstawił założenia teoretyczne wykorzystania bazy ekonomicznej do analizy funkcjonalnej miast, typologii funkcjonalnej miast i charakterystyki współczesnego miasta jako regionu ekonomicznego. Prace Jerczyńskiego dotyczą natomiast specjalizacji bazy ekonomicznej, funkcji wyspecjalizowanych i klasyfikacji funkcjonalnej miast polskich. Interesujące prace o charakterze modelowym przedstawił w tym okresie A. Wróbel (1980). 
Prace Dziewońskiego i Jerczyńskiego stały się inspiracją do studiów funkcji pojedynczych miast (Kozłowski 1977; Suliborski 1991; Łoboda 1992) i sieci miast w granicach województw (Biderman 1967; Zajchowska 1967).

W trzecim okresie (III RP) studia nad funkcjami i strukturą funkcjonalną miast, zwłaszcza wykorzystujące koncepcję bazy ekonomicznej, zaczynają zanikać, co niektórzy (nie bez racji) interpretują jako wyczerpanie się tej koncepcji. W tym czasie powstało jeszcze interesujące opracowanie pokazujące zmiany $\mathrm{w}$ strukturze funkcjonalnej miast Polski w latach 1973-1983 (Matczak 1982) oraz praca przedstawiająca typologię miast Konurbacji Górnośląskiej, omawiająca stan zorganizowania instytucjonalnego miasta (Szajnowska-Wysocka 1995).

Pewnym podsumowaniem koncepcji bazy ekonomicznej i scjentystycznego podejścia do badań funkcji i struktury funkcjonalnej miast jest praca A. Suliborskiego (2001), który w kolejnym obszernym opracowaniu pt. Funkcjonalizm w polskiej geografii miast (Suliborski 2010) przedstawił nową koncepcję badań w zakresie funkcji miejsca. Czas da odpowiedź, czy i w jakim stopniu ta propozycja zostanie wykorzystana $\mathrm{w}$ badaniach geografów.

\section{Struktury przestrzenne miast}

Każda jednostka osadnicza zajmuje określony fragment przestrzeni geograficznej. Chęć poznania różnorodności wykorzystania tej przestrzeni i poszukiwanie dających się określić prawidłowości $w$ jej organizacji i użytkowaniu legły u podstaw podejmowania badań nad wewnętrznymi strukturami przestrzennymi miast.

Wykorzystując zaproponowane wcześniej przez S. Liszewskiego (1994) główne nurty badań nad strukturami przestrzennymi miast, omówimy dorobek polskich geografów w zakresie badań nad strukturami morfologicznymi, funkcjonalnymi, geodemograficznymi i społecznymi.

Struktury morfologiczne miast, rozumiane jako zróżnicowanie budowy wewnętrznej (kształt, wielkość, układ, położenie działki i jednostki morfologicznej) i zewnętrznej (fizjonomia zabudowy i krajobraz miejski) omówione zostały w podrozdziale 3.3, dlatego wymienimy tu tylko przykładowo miasta, dla których określono tę strukturę przestrzenną oraz wskażemy nazwiska autorów prac. Są to miasta śląskie: Opole, Gliwice, Bytom, Racibórz (Golachowski), Opole i Wrocław (Miszewska), Kielce (Kwiatkowski), Radom (Witkowski), Łódź (Koter, Kulesza, Wiktorowska). Badania nad Łodzią zaowocowały nie tylko opracowaniem struktury morfologicznej miasta, lecz także wzorowym planem jego struktury morfogenetycznej (Koter 1979). 
Struktury funkcjonalno-przestrzenne miast przedstawiają podział przestrzeni miejskiej (zwykle wcześniej zorganizowanej geodezyjnie) według pełnionych funkcji. Efektem takich badań w okresie II RP były tzw. mapy krajobrazowe, w drugim i trzecim okresie - mapy użytkowania ziemi. Plany krajobrazowe miast, o czym już pisano wcześniej, wykonano m.in. dla Tarnowa (Simche), Nowego Sącza (Kubijowicz) i Krakowa (Mrazkówna).

Za inicjatora badań nad użytkowaniem ziemi w miastach w okresie PRL uznaje się K. Bromka (1955), który opublikował artykuł metodyczny dotyczący opracowania szczegółowej mapy użytkowania ziemi dla Krakowa. W opracowaniu mapy dla Krakowa uczestniczyli m.in. K. Bromek, Z. Górka, R. Mydel, G. Prawelska-Skrzypek (która przeprowadziła również badania w Rzeszowie) i inni.

Strukturę funkcjonalno-przestrzenną miast w Polsce, na podstawie map użytkowania ziemi, badali również: J. Grocholska (Warszawa), M. Gaczek (Poznań), S. Liszewski (Łódź), A. Werwicki (miasto średnie), R. Matykowski (Gniezno), A. Matczak (Łask), R. Mydel (Kraków), A. Matczak, D. Szymańska (Brodnica).

Analizę struktury funkcjonalno-przestrzennej w ujęciu dynamicznym przeprowadziła dla Lublina D. Kociuba (2011). Jest to jedna z nielicznych tego typu prac, która powstała w okresie III RP.

Obok prac, które prezentują kompleksowo strukturę funkcjonalno-przestrzenną dla całego miasta, coraz częściej pojawiają się opracowania struktury przestrzennej wybranych funkcji miejskich. Przykładowo można tu wymienić: analizę rozmieszczenia terenów przemysłowych Łodzi (Kotlicka 2008), tereny akademickie w mieście (Wolaniuk 2010; Miszewska, Szmytkie 2012), tereny usług handlowych (Dzieciuchowicz 2013), tereny użytkowane przez biura (Jaroszewska, Stryjakiewicz 2009) czy tereny mieszkaniowe (Gaczek 1979; Dzieciuchowicz 1980; Kaczmarek 1996; Groeger 2013). Praktycznie dopiero po roku 1990 (III RP) geografowie polscy podjęli badania nad terenami użytkowanymi przez wojsko w miastach w kontekście ich zmian i przekształceń pod kątem pełnienia innych funkcji.

Do trwałego dorobku polskich badań nad strukturami użytkowania ziemi w miastach należy zaliczyć modele tych struktur, których twórcami byli m.in.: P. Korcelli (1974), R. Matykowski (1990), A. Werwicki (1973) i S. Liszewski (1977).

Struktury geodemograficzne miast, zwłaszcza dużych, dotyczą zmian w rozmieszczeniu ludności w przestrzeni miejskiej, z uwzględnieniem: płci i wieku, gęstości zaludnienia, ruchu naturalnego i innych cech demograficznych. Jako przykłady takich badań mogą posłużyć opracowania dla Krakowa (Bromek 1964), Łodzi (Dzieciuchowicz 1983) i Warsza- 
wy (Gawryszewski 2009), co oczywiście nie zamyka rejestru prac prowadzonych nad strukturami geodemograficznymi w Polsce. Celem badania zmian przestrzennej struktury demograficznej w czasie i w przestrzeni jest określenie faz rozwoju miasta, a zwłaszcza - procesu przemieszczeń ludności na osi centrum-peryferie, w różnych etapach rozwoju miasta.

Struktury społeczno-przestrzenne miast. Obok wymienionych już wcześniej struktur przestrzennych miast, współczesne badania geografów w dużym stopniu koncentrują się na inwentaryzacji, wyjaśnieniu zastanego stanu i poszukiwaniu prawidłowości zróżnicowania przestrzeni miejskiej ze względu na cechy społeczne jego mieszkańców. Zróżnicowanie to dotyczy takich cech, jak: religia, poglądy polityczne, zamożność, wykształcenie, przestępczość, warunki życia, zawód, rasa i inne. Polska literatura geograficzna jest już dziś bardzo bogata, głównie w prace rejestrujące pewne cechy oraz ich analizy w przestrzeni miejskiej. Ramy tego opracowania nie pozwalają na szczegółowe omówienie tych publikacji, dlatego zasygnalizujemy tu tylko, naszym zdaniem, najważniejsze z nich.

Jedną $\mathrm{z}$ pierwszych prac powstałych $\mathrm{w}$ okresie PRL była książka J. Brauna (1964) o elementach ekologii miasta przemysłowego. O podnoszonych w niej problemach może świadczyć fakt, że była ona zastrzeżona i nie weszła do ogólnego obiegu. Niewątpliwie najważniejszą praca, która powstała w II okresie (PRL) była książka habilitacyjna G. Węcławowicza (1988) pt. Struktury społeczno-przestrzenne w miastach Polski. Autor, posługując się metodą ekologii czynnikowej, dokonał porównań struktury społeczno-przestrzennej trzech miast: Radomia, Katowic i Krakowa w latach 1970-1978.

O ile wymieniona praca G. Węcławowicza miała charakter teoretyczno-empiryczny, o tyle dwa wydania podręcznika akademickiego pt. Geografia społeczna miast (Węcławowicz 2003, 2007) poszerzyły tę problematykę, dając przegląd podstaw teoretycznych, co zaowocowało licznymi pracami na temat różnych aspektów społecznych w strukturach przestrzennych miast. Przykładowo tylko wymienimy tu prace: S. Kaczmarek (1996) o warunkach zamieszkania w Łodzi; Sz. Marcińczaka (2009) o przemianach struktury społecznej miasta; S. Mordwy (2013) na temat przestępczości i poczucia bezpieczeństwa w przestrzeni miasta; S. Liszewskiego (1999) o elitach intelektualnych w przestrzeni miasta, L. Przybylskiej (2014) i E. Klimy (2011) o sakralizacji przestrzeni publicznej, a także habilitację M. Sobczyńskiego (2000) o zróżnicowaniu postaw politycznych mieszkańców Łódzi.

Prac powstałych w ostatnim okresie (III RP) jest znacznie więcej, co może świadczyć o atrakcyjności tematyki związanej ze strukturą społeczno-przestrzenną miasta, ale jednocześnie o braku wykrystalizowanej metodologii badań tych problemów. 
Na zakończenie warto odnotować ukazanie się interesującej dwutomowej pracy autorstwa J. Paryska i L. Mierzejewskiej $(2013,2014)$ pt. Życie miasta, która może zapowiadać nowy nurt badawczy, obejmujący (teoretycznie i kompleksowo) problematykę badań społecznych miasta. Strukturom przestrzennym miast $\mathrm{w}$ tym opracowaniu poświęcono nieco więcej miejsca, co jest związane z wyraźnie wzrastającym zainteresowaniem geografów tą tematyką. Dotyczy to zwłaszcza problematyki społecznej w miastach.

\section{Sieć i system osadniczy}

Geografowie od dawna zajmowali się rozmieszczeniem osiedli w przestrzeni geograficznej i ich połączeniami za pomocą sieci komunikacyjnej. Prace poświęcone temu zagadnieniu omawia E. Biderman (1994), prezentując badania polskich geografów w początkach XX w. (okres II RP). Pojęcie sieci osadniczej zostało uściślone w okresie PRL, a Jażdżewska (2008) definiuje ją jako „zbiór miast (węzłów) położonych w przestrzeni geograficznej oraz ich połaczeń (linii) rozumianych głównie jako szlaki komunikacyjne". Szczególnie duże zainteresowanie siecią osadniczą nastąpiło wśród polskich geografów po wydaniu pracy M. Chilczuka (1963) o sieci ośrodków więzi społeczno-gospodarczej w Polsce, w której została wykorzystana opublikowana w 1933 r. koncepcja ośrodków centralnych W. Christallera (Jażdżewska 2012).

Rozwój badań nad funkcjami miast, a zwłaszcza bazą ekonomiczną i rolą funkcji wyspecjalizowanych, zrodził nową koncepcję badawcza, wyjaśniającą rozmieszczenie i wzajemne związki między miastami. Koncepcja ta, zwana systemem osadniczym, znalazła wielu badaczy, którzy podjęli pracę nad lokalnymi, regionalnymi i krajowymi systemami osadniczymi (Maik 1994). Mogą świadczyć o tym również cztery prace habilitacyjne, które powstały praktycznie w trzecim z omawianych w tym opracowaniu okresie. Ich autorami byli: W. Maik (1988), M. Sokołowski (2006), I. Jażdżewska (2008) oraz I. Jażewicz (2013). Przykłady powstania, rozwoju i przemian krajowych systemów osadniczych miast zaprezentowali również S. Liszewski i W. Maik (2000) w Wielkiej encyklopedii geografii świata.

\section{Inne kierunki (pola badawcze)}

Obok ośmiu, omówionych w tej pracy i od lat uprawianych przez polskich geografów, kierunków badań nad osadnictwem, inwencja twórcza, zwłaszcza młodego pokolenia, zaowocowała podjęciem bardzo szeroko zakrojonych nowych badań. Szeroki zakres przedmiotowy i różne 
koncepcje metodologiczne wykorzystane do prowadzenia tych badań, utrudniają połączenie ich wspólną nazwą. Aby jednak nie tracić z pola widzenia często interesujących i aktualnych poznawczo pomysłów badawczych, postanowiono przykładowo tylko wymienić je w tej pracy, łącząc w kilka umownie nazwanych pól badawczych.

\section{Procesy związane z powstaniem, rozwojem i przemianami miast}

Tak określone pole badawcze jest miejscem krzyżowania się zainteresowań przedstawicieli różnych dziedzin i dyscyplin naukowych, z którymi geografowie współpracuja, ale także konkurują. Wśród całej gamy procesów towarzyszących powstawaniu, rozwojowi i przebudowie miast trwają badania m.in. nad:

- procesami urbanizacji, w tym suburbanizacji i semiurbanizacji (Szymańska 2008; Heffner 2011; Jażdżewska [red.] 2005, a także kontrurbanizacji (Grzeszczak 1996);

- procesami rewitalizacji, których natężenie związane jest m.in. z upadkiem przemysłu na terenie miast (Kaczmarek 2001; Markowski, Kaczmarek, Olenderek [red.] 2010; Wojnarowska, Kozłowski 2011);

- procesami gentryfikacji, czyli procesami związanymi ze społeczną przebudową miast (Grzeszczak 2010; Jakóbczyk-Gryszkiewicz [red.] 2012, 2013, 2015);

- procesami kurczenia się miast, głównie wyrażającymi się zmniejszaniem liczby mieszkańców (Stryjakiewicz [red.] 2014);

- procesami demilitaryzacji miast, likwidacją garnizonów wojskowych w miastach (Szymańska 2006; Krzemiński, Sikorski 2010);

- sakralizacją przestrzeni miejskiej (Przybylska 2014; Klima 2011);

- procesami związanymi z powstaniem, rozwojem i przemieszczaniem się centrów miast (Wolaniuk 1994; Wolaniuk [red.] 2014);

- rozwojem funkcji turystycznej, m.in. w miastach przemysłowych (Kaczmarek 2012; Pytel, Zuzańska-Żyśko 2010; Jażdżewska [red.] 2008);

2. Ważnym polem badawczym dla geografów zajmujących się miastami od kilku lat stała się przestrzeń miejska rozumiana jako obszar zagospodarowania (użytkowania) miejskiego, ale przede wszystkim jako przestrzeń społeczna, kreowana i kształtowana przez człowieka. Przykładowo tylko wymienimy tu niektóre prace, z których część jest pokłosiem konferencji naukowych organizowanych na ten temat (Parysek [red.] 2012; Szkurłat 2004; Kotus 2005; Suliborski, Wójcik [red.] 2014; Madurowicz [red.] 2010, 2014; Szymańska 2011; Jażdżewska [red.] 2006; Wolaniuk 2010).

3. Miasta postsocjalistyczne. Ten problem badawczy, który zrodził się przed 25 laty, nie spotkał się w Polsce $\mathrm{z}$ większym zainteresowaniem 
Rozwój badań geograficznych nad osadnictwem w Polsce...

wśród geografów (w odróżnieniu od badaczy z krajów Europy Zachodniej, ale również Czech czy Węgier). Sygnalizujemy go w tym miejscu, aby wskazać, że to pole badawcze jest ważne nie tylko jako zjawisko historyczne, lecz także jako dynamiczny proces dokonujący się codziennie na naszych oczach. Wśród prac, które powstały na ten temat trzeba wyróżnić pracę habilitacyjną Sz. Marcińczaka (2013), artykuł S. Liszewskiego (2007) i materiały dwóch „Konwersatoriów Wiedzy o Mieście” (Jażdżewska 2000, 2001).

4. Na zakończenie tego przeglądu nie sposób nie odnieść się do tradycyjnego dla geografów pola badawczego, jakim były studia monograficzne. Przeglądając wydane w ostatnich latach monografie miast przygotowane przez geografów stwierdzam, że ich liczba jest niewspółmierna do potencjału badawczego tego środowiska. Geografowie dali się tu zdystansować historykom, nie umiejąc czy nie chcąc zaprezentować oryginalnej geograficznej monografii miasta, na co dziś pozwala rozwój wszechstronnych badań geograficznych nad miastami, zarówno w nurcie przyrodniczym, jak i gospodarczym, a nade wszystko społecznym.

Dla przypomnienia wymieniam tu kilka monografii miast, przygotowanych przez geografów: Tarnów (Simche 1930), Kluczbork (Straszewicz [red.] 1970), Szadek (Marszał 1995), Łódź (Liszewski [red.] 2009), Lublin (Kociuba 2011).

Tabela 1. Główne kierunki badań geografów polskich nad osadnictwem w latach 1918-2015

\begin{tabular}{|c|l|c|c|c|}
\hline L.p. & Kierunki badań. Pola badawcze & $\begin{array}{c}\text { Okres I } \\
\text { (do 1930 } \\
- \text { II RP) }\end{array}$ & $\begin{array}{c}\text { Okres II } \\
\text { (1945-1989 } \\
- \text { PRL) }\end{array}$ & $\begin{array}{c}\text { Okres III } \\
\text { (po 1990 } \\
\text { - III RP) }\end{array}$ \\
\hline 1. & $\begin{array}{l}\text { Wpływ środowiska geograficznego } \\
\text { na powstanie i rozwój osadnictwa }\end{array}$ & ++ & + & - \\
\hline 2. & Osadnictwo wiejskie & + & ++ & + \\
\hline 3. & Studia geograficzno-historyczne miast & + & ++ & + \\
\hline 4. & Studia nad małymi i średnimi miastami & + & ++ & + \\
\hline 5. & Wielkie skupiska miejskie & - & ++ & + \\
\hline 6. & Funkcje i struktury funkcjonalne miast & - & ++ & $+\bullet$ \\
\hline 7. & Struktury przestrzenne miast & + & +++ & + \\
\hline 8. & Sieć i system osadniczy & - & ++ & + \\
\hline & $\begin{array}{l}\text { Inne pola badań (procesy zachodzące } \\
\text { w miastach, przestrzeń miejska, miasta } \\
\text { posocjalistyczne, geografia społeczna } \\
\text { miast, geograficzne monografie miast } \\
\text { i inne) }\end{array}$ & - & + & + \\
\hline
\end{tabular}

Objaśnienia: + badania podstawowe; ++ intensywne badania podstawowe; • nowe koncepcje badawcze; - badania śladowe. 


\section{Zakończenie. Wnioski}

W przedstawionej pracy, w miarę możliwości autora, dokonano wnikliwej analizy dorobku geografów w zakresie badania osadnictwa. Jako podsumowanie tych badań przedstawiono tabelę pozwalającą na uchwycenie zmienności i natężenia badań w czasie (około 100 lat) wg głównych kierunków i pól badawczych. Zebrany materiał umożliwia dostrzeżenie określonych „ścieżek życia” każdego z wytypowanych kierunków badań.

Przeprowadzona analiza pozwala na sformułowanie uogólnień i wyciągnięcie wniosków.

W badanym okresie nastąpił bardzo wyraźny wzrost liczby kierunków badań, a także zaszły zmiany dotyczące prowadzonej tematyki. Najogólniej rzecz ujmując, geografowie w okresie II RP zajmowali się osadnictwem wiejskim i małymi miastami, uwzględniając $\mathrm{w}$ tych badaniach głównie dwa czynniki: przeszłość (historię) i środowisko przyrodnicze. Na podkreślenie zasługuje bogaty i znaczący dorobek badania miast wg programu L. Sawickiego.

Drugi z badanych okresów (PRL), który trwał najdłużej, zaznaczył się bardzo szerokim wachlarzem badań osadnictwa przez geografów. Obok kontynuacji kierunków badawczych pierwszego okresu rozwinięto badania funkcjonalne (baza ekonomiczna), badania nad strukturami przestrzennymi miast (morfologiczne i funkcjonalne), nad wielkimi skupiskami miejskimi (aglomeracje, region miejski, metropolie i inne), a także nad siecią i systemem miast. Znamienne, że w okresie tym geografowie polscy głównie adaptowali metodologię badań z zagranicy, przy nielicznych własnych teoretycznych koncepcjach badań.

Trzeci okres odznacza się zanikiem niektórych uprawianych wcześniej kierunków badań (studia geograficzno-historyczne, osadnictwo wiejskie, struktury funkcjonalne miast) i rozwojem, ale w sposób chaotyczny, badań społeczno-geograficznych. Powstają w tym czasie interesujące koncepcje nowych badań nad osadnictwem wiejskim, a także nad funkcją miejsca czy życiem miasta. Moim zdaniem, sygnały te dobrze rokują w sprawie powstania zintegrowanej koncepcji geograficznego badania osadnictwa.

Analiza wykazała również możliwości prowadzenia przez geografów badań cyklicznych osadnictwa. Dobrym przykładem są tu badania małych miast, które $\mathrm{w}$ każdym $\mathrm{z}$ prezentowanych okresów były podejmowane, głównie ze względu na zapotrzebowanie społeczne. Szkoda, że ten dorobek nie doczekał się uogólnienia i syntezy o charakterze metodologiczno-metodycznym.

Bardzo różnorodne badania podjęto w trzecim okresie (III RP), głównie nad procesami związanymi z rozwojem, upadkiem i przekształceniami osadnictwa miejskiego (inne kierunki badań). Szkoda, że odbywają się 
Rozwój badań geograficznych nad osadnictwem w Polsce...

one w dużym rozproszeniu, co utrudnia bardziej precyzyjne uogólnienia. Pewien niepokój budzi brak większego zainteresowania tematyką miasta postsocjalistycznego oraz metodologią geograficznej monografii miast.

Po zapoznaniu się z dotychczasowym (bardzo bogatym) dorobkiem geografów w zakresie badań osadnictwa sądzę, że największymi ich mankamentami są słabe wpisanie w podstawy teoretyczno-metodologiczne i wielkie rozproszenie. Pierwszy mankament potwierdza fakt słabego odzewu (o ile mi wiadomo), z jakim się spotkała jedna z nielicznych w całym badanym okresie prac teoretycznych autorstwa W. Maika (2012) - Podstawy teoretyczno-metodologiczne studiów geograficzno-miejskich. Studium z metodologii geografii miast. Druga słabość, moim zdaniem, może być pokonana przez podjęcie przez geografów kilku dużych, obejmujących różne ośrodki, programów badawczych.

\section{Literatura}

Bański J. (2006), Geografia polskiej wsi, PWE, Warszawa.

Bartosiewicz B., Marszał T. (2011), Gospodarka małych miast z perspektywy 20 lat transformacji, Wyd. Uniwersytetu Łódzkiego, Łódź.

Biderman E. (1967), Sieć osiedli miejskich województwa koszalińskiego oraz ich strefy wptywów, PTPN, Poznań.

Biderman E. (1994), Badania sieci osadniczej w Polsce w latach 1918-1993, [w:] S. Liszewski (red.), Geografia osadnictwa i ludności w niepodległej Polsce. Lata 1918-1993, t. 2, PTG, Łódź, s. 201-218.

Braun J. (1964), Elementy ekologii miasta przemysłowego, „Biuletyn Zakładu Badań Naukowych Górnośląskiego Okręgu Przemysłowego PAN", nr 2.

Bromek K. (1955), Opracowanie szczegółowej mapy użytkowania ziemi dla Krakowa, „Przegląd Geograficzny", t. 27, z. 3-4.

Bromek K. (1964), Rozwój demograficzny regionu Krakowa w okresie od 1989 do 1950 r., „Zeszyty Naukowe UJ", Prace Geograficzne, z. 9.

Chilczuk M. (1965), Sieć ośrodków więzi społeczno-gospodarczej w Polsce, Instytut Geografii i Zagospodarowania Przestrzennego PAN, „Prace Geograficzne”, nr 45, Warszawa.

Czyż T. (2009), Koncepcja aglomeracji miejskiej i obszaru metropolitalnego w Polsce, „Przegląd Geograficzny", t. 81, z. 4.

Dylik J. (1939), Położenie geograficzne Tumu i Łęczycy, „Rocznik Oddziału PTH”, s. 125-128.

Dzieciuchowicz J. (1983a), Kompleksowa rejonizacja warunków mieszkaniowych wielkiego miasta na przykładzie Łodzi, „Acta Universitatis Lodziensis”, Ser. II, Nauki Matematyczno-Przyrodnicze, z. 22.

Dzieciuchowicz J. (1983b), Z badań nad struktura geodemograficzna wielkiego miasta. Segregacja przestrzenna płci i wieku ludności Łodzi, „Acta Universitatis Lodziensis”, Folia Geographica, z. 2.

Dzieciuchowicz J. (2013), Handel w przestrzeni wielkomiejskiej. Przykład Łodzi, Wyd. Uniwersytetu Łódzkiego, Łódź.

Dzieciuchowicz J. (2014), Ludność Łodzi. Rozwój i przemiany strukturalne, Wyd. Uniwersytetu Łódzkiego, Łódź. 
Dziewoński K. (1947), Przeobrażenia osadnictwa miejskiego w Polsce, „Czasopismo Geograficzne", t. 18, z. $1 / 4$.

Dziewoński K. (1956), Geografia osadnictwa i zaludnienia. Dorobek, podstawy teoretyczne i problemy badawcze, „Przegląd Geograficzny”, t. 28, z. 4, s. 721-764.

Dziewoński K. (1962), Zagadnienia typologii morfologicznej miast w Polsce, „Czasopismo Geograficzne", t. 33, z. 4.

Dziewoński K. (1967), Baza ekonomiczna i struktura funkcjonalna miast. Studium rozwoju pojęć, metod $i$ zastosowań, Instytut Geografii i Zagospodarowania Przestrzennego PAN, „Prace Geograficzne”, nr 63.

Dziewoński K. (1983), Geografia osadnictwa i ludności w Polsce 1945-1982. Mechanizmy rozwoju, „Przegląd Geograficzny”, t. 55, z. 3-4, s. 547-565.

Dziewoński K. (1987), Strefa podmiejska - próba ujęcia teoretycznego, „Przegląd Geograficzny", t. 59, s. 5-63.

Dziewoński K. (1990), Geografia osadnictwa i ludności w Polsce 1945-1989. Mechanizmy rozwoju (1982-1989), Instytut Geografii i Zagospodarowania Przestrzennego PAN, „Prace Geograficzne", nr 154, s. 264-285.

Dziewoński K. i in., red. (1957), Studia geograficzne nad aktywizacja matych miast, Instytut Geografii i Zagospodarowania Przestrzennego PAN, „Prace Geograficzne”, nr 9.

Gaczek W. M. (1978), Struktura przestrzeni rezydencjalnej Poznania. Studium analizy czynnikowej, PAN, Oddział w Poznaniu, „Geografia”, t. 4.

Gawryszewski A. (2009), Ludność Warszawy w XX wieku, Instytut Geografii i Zagospodarowania Przestrzennego PAN, „Monografie”, nr 10.

Golachowski S. (1964), Rozłogi miejskie jako przedmiot badań historyczno-geograficznych, „Studia Geograficzne", t. 1.

Golachowski S. (1969), Studia nad miastami i wsiami ślaskimi, Instytut Śląski w Opolu, PWN, Opole-Wrocław.

Gontarski Z. (1972), Delimitacja obszarów metropolitalnych w Polsce, „Statystyka Terenowa”, nr 8.

Gontarski Z. (1973), W sprawie delimitacji i typologii wielkomiejskich układów osadniczych, „Biuletyn KPZK PAN", nr 79.

Groeger L. (2013), Zróżnicowanie i wartościowanie przestrzeni mieszkaniowej na przykładzie miast woj. tódzkiego, Wyd. Uniwersytetu Łódzkiego, Łódź.

Grzeszczak J. (1996), Tendencje kontrurbanizacyjne w krajach Europy Zachodniej, Instytut Geografii i Zagospodarowania Przestrzennego PAN, „Prace Geograficzne”, nr 167, Wrocław.

Grzeszczak J. (2010), Gentryfikacja osadnictwa. Charakterystyka. Rozwój koncepcji badawczej i przegląd wyjaśnień, Instytut Geografii i Zagospodarowania Przestrzennego PAN, „Monografie”, nr 11, Warszawa.

Heffner K. (2011), Semiurbanizacja a suburbanizacja. Ewolucja procesów w aglomeracji opolskiej, "Studia Miejskie", nr 3.

Heffner K., Marszał T. (2005), Problemy rozwoju matych miast w wymiarze lokalnym i regionalnym, „Biuletyn KPZK PAN”, nr 220.

Iwanicka-Lyra E. (1969), Delimitacja aglomeracji wielkomiejskich w Polsce, Instytut Geografii i Zagospodarowania Przestrzennego PAN, „Prace Geograficzne”, nr 76, Warszawa.

Jakóbczyk-Gryszkiewicz J. (1993), Przeobrażenia stref podmiejskich dużych miast. Studium porównawcze strefy podmiejskiej Warszawy, Łodzi i Krakowa, Wyd. Uniwersytetu Łódzkiego, Łódź.

Jakóbczyk-Gryszkiewicz J. [red.] (2011), Regiony miejskie w Polsce. Dwadzieścia lat transformacji. Wyd. Uniwersytetu Łódzkiego, Łódź. 
Rozwój badań geograficznych nad osadnictwem w Polsce...

Jakóbczyk-Gryszkiewicz J. [red.] (2012, 2013), Procesy gentryfikacji w mieście, cz. I i II, XXV i XXVI Konwersatorium Wiedzy o Mieście, Łódź.

Jakóbczyk-Gryszkiewicz J. [red.] (2015), Procesy gentryfikacji w obszarach śródmiejskich wielkich miast. Na przykładzie Warszawy, Łodzi i Gdańska, „Studia KPZK PAN”, t. 165, Warszawa.

Jakóbczyk-Gryszkiewicz J., Paradowska E. [red.] (1995), Bibliografia prac z zakresu geografii osadnictwa i ludności w latach 1990-1994, PTG, Łódź.

Jałowiecki B. (1999), Metropolie, Wyższa Szkoła Finansów i Zarządzania, Białystok.

Janiszewski M. (1973), Rola granic fizjograficznych w powstawaniu miast na nizinach polskich, "Geografia w Szkole", nr 5.

Janiszewski M. (1991), Geograficzne warunki powstania miast polskich, Wyd. Uniwersytetu Marii Curie-Skłodowskiej, Lublin.

Jaroszewska R., Maik W. (1994), Studia nad struktura funkcjonalna miast, [w:] S. Liszewski (red.), Geografia osadnictwa i ludności w niepodległej Polsce. Lata 1918-1939, t. 2, PTG, Komisja Geografii Osadnictwa i Ludności, Łódź.

Jaroszewska E., Stryjakiewicz T. (2009), Lokalizacja obiektów biurowych w Poznaniu, Bogucki Wyd. Naukowe, Poznań.

Jażdżewska I. [red.] (2000, 2001), Miasto postsocjalistyczne - organizacja przestrzeni miejskiej i jej przemiany, cz. I i II, XIII i XIV Konwersatorium Wiedzy o Mieście, Łódź.

Jażdżewska I. [red.] (2002), Funkcje metropolitalne i ich rola w organizacji przestrzeni, XVI Konwersatorium Wiedzy o Mieście, Łódź.

Jażdżewska I. [red.] (2005), Wspótczesne procesy urbanizacji i ich skutki, XVIII Konwersatorium Wiedzy o Mieście, Łódź.

Jażdżewska I. [red.] (2006), Nowe przestrzenie w miastach, ich organizacja i funkcje, XIX Konwersatorium Wiedzy o Mieście, Łódź.

Jażdżewska I. [red.] (2008a), Funkcja turystyczna miast, XXI Konwersatorium Wiedzy o Mieście, Łódź.

Jażdżewska I. (2008b), Przemiany miejskiej sieci osadniczej w Polsce. W świetle metod matematycznych, Wyd. Uniwersytetu Łódzkiego, Łódź.

Jażdżewska I. (2012), Sieć i system osadniczy miast, [w:] Liszewski S. (red.), Geografia urbanistyczna, Wyd. Naukowe PWN, Warszawa, s. 343-378.

Jażewicz I. (2013), Miejska sieć osadnicza regionu nadmorskiego, Akademia Pomorska w Słupsku, Słupsk.

Jerczyński M. (1971), Metody pośrednie, identyfikacja i pomiar. Baza ekonomiczna i struktura funkcjonalna miast, Instytut Geografii i Zagospodarowania Przestrzennego PAN, „Prace Geograficzne", nr 87, Wrocław.

Jerczyński M. (1973), Zagadnienia specjalizacji bazy ekonomicznej większych miast w Polsce, [w:] K. Dziewoński (red.), Studia nad struktura funkcjonalna miast, Instytut Geografii i Zagospodarowania Przestrzennego PAN, „Prace Geograficzne”, nr 97, Wrocław.

Jerczyński M. (1977), Funkcje i typy funkcjonalne miast (zagadnienie dominacji funkcjonalnej), [w:] Statystyczna charakterystyka miast. Funkcje dominujace, „Statystyka Polski”, nr 85.

Kaczmarek J. (2012), Egzo- i endogeniczna gospodarka turystyczna jako przykład kreowania i zarządzania przestrzenia w mieście, „Studia Miejskie”, nr 7.

Kaczmarek S. (1996), Struktura przestrzenna warunków zamieszkania w Łodzi, ŁTN, Łódź.

Kaczmarek S. (2001), Rewitalizacja terenów poprzemysłowych. Nowy wymiar w rozwoju miasta, Wyd. Uniwersytetu Łódzkiego, Łódź.

Kiełczewska-Zaleska M. (1931), Osadnictwo wiejskie Wielkopolski, „Badania Geograficzne nad Polską Północno-Zachodnią", t. 14, Poznań, s. 1-41.

Kiełczewska-Zaleska M. (1947), O położeniu Torunia, „Czasopismo Geograficzne”, t. 18. 
Kiełczewska-Zaleska M. (1953), O położeniu geograficznym Poznania, „Geografia w Szkole”, z. 6.

Kiełczewska-Zaleska M. (1956), O powstaniu i przeobrażeniu kształtów wsi Pomorza Gdańskiego, Instytut Geografii i Zagospodarowania Przestrzennego PAN, „Prace Geograficzne", nr 5, Warszawa.

Kiełczewska-Zaleska M. (1963), Nowe kierunki studiów geograficzno-historycznych nad osadnictwem wiejskim, „Przegląd Geograficzny”, t. 35, s. 3-19.

Kiełczewska-Zaleska M. (1964), Rozwój badań geograficznych osadnictwa wiejskiego w Polsce, „Czasopismo Geograficzne”, t. 35, s. 337-353.

Kiełczewska-Zaleska M. (1969), Geografia osadnictwa. Zarys problematyki, PWN, Warszawa.

Klima E. (2011), Przestrzeń religijna miasta, Wyd. Uniwersytetu Łódzkiego, Łódź.

Kobojek E., Marszał T. (2014), Local development and the role of small town in space organization in contemporary Poland, [w:] Spatial Development of Contemporary Poland in Łódź, University Geographical Research, Wyd. Uniwersytetu Łódzkiego, Łódź, s. 37-60.

Kociuba D. (2011), Lublin. Rozwój przestrzenny i funkcjonalny od średniowiecza do wspótczesności, Wyd. Adam Marszałek, Torun.

Korcelli P. (1974), Teoria rozwoju struktury przestrzennej miast, „Studia KPZK PAN”, nr 45, Warszawa.

Korcelli P. (1981), Regiony miejskie w systemie osadniczym Polski, Instytut Geografii i Zagospodarowania Przestrzennego PAN, „Prace Geograficzne”, nr 140, Warszawa-Wrocław.

Korcelli P. (1998), Metropolia i funkcje metropolitalne - podstawowe pojęcia i ich zakres, „Zeszyty IGiPZ PAN", Warszawa.

Korcelli-Olejniczak E. (2004), Funkcje metropolitarne Warszawy i Berlina w latach 1990-2002. Wspótzależność pozycji w systemie miast Europy Środkowej, Instytut Geografii i Zagospodarowania Przestrzennego PAN, „Prace Geograficzne”, nr 198, Warszawa.

Korcelli-Olejniczak E. (2012), Region metropolitalny - pojęcie, struktura przestrzenna, dynami$k a$, Instytut Geografii i Zagospodarowania Przestrzennego PAN, „Prace Geograficzne", nr 235, Warszawa.

Kosiński L. (1958), Zagadnienia struktury funkcjonalnej miast polskich, „Przegląd Geograficzny", t. 30, z. 1.

Kosiński L. (1967), Geografia ludności, PWN, Warszawa.

Kostrowicki J. (1952), O funkcjach miastotwórczych i typach funkcjonalnych miast, „Przegląd Geograficzny", t. 24, z. 1-2.

Koter M. (1969), Geneza układu przestrzennego Łodzi przemysłowej, , Instytut Geografii i Zagospodarowania Przestrzennego PAN, „Prace Geograficzne”, nr 79, Warszawa.

Koter M. (1979), Struktura morfogenetyczna wielkiego miasta na przykładzie Łodzi, "Acta Universitatis Lodziensis", Zeszyty Naukowe Uniwersytetu Łódzkiego, Seria II, Nauki Matematyczno-Przyrodnicze, z. 21.

Koter M. (1994), Od fizjonomii do morfogenezy i morfologii porównawczej. Podstawowe zagadnienia teoretyczne morfologii miast, Torun-Łódź.

Koter M., Kulesza M. (1994), Badania geograficzno-historyczne osadnictwa miejskiego w Polsce w latach 1918-1993, [w:] S. Liszewski (red.), Geografia osadnictwa i ludności w latach 1918-1993, t. 2, PTG, Łódź, s. 131-158.

Koter M., Kulesza M. (2007), Morfologia miast - stan i tendencje rozwoju, XX Konwersatorium Wiedzy o Mieście, Wyd. Uniwersytetu Łódzkiego, Łódź, s. 303-314.

Koter M., Wiktorowska D. (1976), Proces przemian morfologicznych śródmieścia Łodzi (w granicach byłej kolonii tkackiej) pod wptywem kształtowania się ogólnomiejskiego centrum usługowego, "Acta Universitatis Lodziensis”, Zeszyty Naukowe Uniwersytetu Łódzkiego, Seria II, Nauki Matematyczno-Przyrodnicze, z. 7. 
Rozwój badań geograficznych nad osadnictwem w Polsce...

Kotlicka J. (2008), Przemiany morfologiczne terenów przemysłowych Łodzi, „Szlakami Nauki”, nr 36, ŁTN, Łódź.

Kotus J. (2005), Społeczne dylematy w przestrzeni miejskiej, Bogucki Wydawnictwo Naukowe, Poznań.

Kozłowski S. (1977), Zielona Góra. Baza ekonomiczna i powiąania zewnętrzne, Instytut Geografii i Zagospodarowania Przestrzennego PAN, „Prace Geograficzne”, nr 126, Wrocław.

Krzemiński P., Sikorski D. (2010), Rola jednostek wojskowych we współczesnych procesach przemian struktury przestrzennej miasta na przykładzie Łasku, „Studia Miejskie”, nr 2. s. 285293.

Krzysztofik R. (2014), Geneza aglomeracji miast na obszarze Polski, Wydawnictwo Uniwersytetu Śląskiego, Katowice.

Kształtowanie przestrzeni miejskiej. Aspekty teoretyczne i praktyczne (2012), red. J. J. Parysek, Wyd. Uniwersytetu A. Mickiewicza, Poznań-Kalisz.

Kulesza M. (2001), Morfogeneza miast na obszarach Polski Środkowej w okresie przedrozbiorowym. Dawne województwa łęczyckie i sieradzkie. Wydawnictwo UŁ, Łódź.

Kulesza M. (2011), Zagadnienia morfogenezy i rozplanowania miast średniowiecznych w Polsce, Wydawnictwo Ibidem, Łódź.

Kurczenie się miast w Europie Środkowo-Wschodniej (2014), red. T. Stryjakiewicz, Bogucki Wydawnictwo Naukowe, Poznań.

Kwiatek-Sołtys A. (2011), Małe miasta w polskiej literaturze geograficznej ostatniego dwudziestolecia, [w:] B. Bartosiewicz, T. Marszał T. (red.), Kierunki i uwarunkowania rozwoju małych miast z perspektywy 20 lat transformacji. Studium przypadków, Wydawnictwo UŁ, Łódź, s. $9-55$.

Leszczycki S. (1932), Badania geograficzne nad osadnictwem w Beskidzie Wyspowym, „Prace Instytutu Geograficznego UJ", Kraków.

Leszczycki S., Eberhardt P., Heřman S. (1971), Aglomeracje miejsko-przemysłowe w Polsce 1966-2000, „Biuletyn KPZK PAN”, z. 67, Warszawa.

Liszewski S. (1977), Tereny miejskie a struktura przestrzenna Łodzi, Uniwersytet Łódzki, Łódź.

Liszewski S. (1987), Strefa podmiejska jako przedmiot badań geograficznych. Próba syntezy, „Przegląd Geograficzny”, t. 59, z. 1-2.

Liszewski S. (1993), Dorobek tódzkiego ośrodka geograficznego w zakresie badania ośrodków lokalnych. Próba syntezy, kierunki dalszych prac, [w:] red. W. Maik, Problematyka lokalnych systemów osadniczych, Uniwersytet M. Kopernika, Toruń, s. 29-40.

Liszewski S. [red.] (1993, 1994, 1995), Geografia osadnictwa i ludności niepodległej Polsce. Lata 1918-1993, t. 1: Ośrodki naukowo badawcze i ich dorobek, t. 2: Kierunki badań naukowych, t. 3: Badacze, PTG, Łódź.

Liszewski S. (1994), Studia nad strukturami przestrzennymi miast, [w:] S. Liszewski (red.), Geografia osadnictwa i ludności w niepodległej Polsce. Lata 1918-1993, t. 2, PTG, Łódź.

Liszewski S. (1995), Geografia miast nadrzecznych, [w:] J. Kułtuniak (red.), Rzeki - Kultura - Cywilizacja-Historia, t. 4, Wydawnictwo Śląsk, Katowice, s. 127-151.

Liszewski S. (1999), Elity intelektualne w przestrzeni miasta. Przykład Łodzi, XI Konwersatorium Wiedzy o Mieście, Łódź.

Liszewski S. (2007), Ewolucja miast w posocjalistycznych krajach Europy Centralnej (Projekt badań), „XX Konwersatorium Wiedzy o Mieście”, red. I. Jażdżewska, Wyd. Uniwersytetu Łódzkiego, Łódź, s. 315-322.

Liszewski S. (2008), Geografia osadnictwa w XX i na poczatku XXI w., [w:] red. A. Jackowski, S. Liszewski, A. Rychling, Historia geografii polskiej, Wydawnictwo Naukowe PWN, Warszawa, s. 161-176.

Liszewski S. [red.] (2008), Geografia urbanistyczna, Wyd. Uniwersytetu Łódzkiego, Łódź. 
Liszewski S. [red.] (2009), Łódź. Monografia miasta, ŁTN, Łódź.

Liszewski S. (2010), Metropolia jako przedmiot badań naukowych i obszar dynamicznych przemian przestrzennych oraz społeczno-gospodarczych, „Biblioteka Wiadomości Statystycznych", nr 63, GUS, Warszawa, s. 27-41.

Liszewski S. [red.] (2012), Geografia urbanistyczna, wyd. II, Wydawnictwo Naukowe PWN, Warszawa.

Liszewski S., Maik W. (2000), Osadnictwo, [w:] Wielka encyklopedia geografii świata, t. 19, Wydawnictwo Kurpisz, Poznań.

Liszewski S., Maik W. (2005), Rola i miejsce geografii osadnictwa i ludności w systemie nauk geograficznych, „,Studia i Materiały IGiGP Wyższej Szkoły Gospodarki w Bydgoszczy”, nr 1.

Liszewski S., Maik W. (2008), Stan i perspektywy rozwoju geografii osadnictwa w Polsce, [w:] S. Liszewski, J. Łoboda, W. Maik (red.), Stan i perspektywy rozwoju geografii w Polsce, KNG PAN, Wyższa Szkoła Gospodarki w Bydgoszczy, Bydgoszcz, s. 176-180.

Łoboda J. (1992), Funkcjonowanie i delimitacja Wroctawia, „Acta Universitatis Lodziensis”, Folia Geopraphica, z. 17.

Madurowicz M. [red.] (2010), Wartościowanie wspótczesnej przestrzeni miejskiej, Uniwersytet Warszawski, Urząd Miasta Stołecznego Warszawy, Warszawa.

Madurowicz M. [red.] (2014), Kształtowanie współczesnej przestrzeni miejskiej, Wyd. Uniwersytetu Warszawskiego, Warszawa.

Maik W. (1988), Rozwój teorii regionalnych i krajowych układów osadniczych, „Seria Geografia”, nr 37, Wyd. Naukowe Uniwersytetu A. Mickiewicza, Poznań.

Maik W. (1992), Podstawy geografii miast, Wyd. Uniwersytetu Mikołaja Kopernika, Toruń.

Maik W. (1994), Badania systemów osadniczych w Polsce w latach 1970-1993, [w:] S. Liszewski (red.), Geografia osadnictwa i ludności w niepodległej Polsce. Lata 1918-1993, t. 2, PTG, Łódź, s. 219-230.

Maik W. (2012), Podstawy teoretyczno-metodologiczne studiów geograficzno-miejskich. Studium z metodologii geografii miast, Wyższa Szkoła Gospodarki w Bydgoszczy, Bydgoszcz.

Marcińczak S. (2009), Przemiany struktury społeczno-przestrzennej Łodzi w latach 1988-2005, Wyd. Uniwersytetu Łódzkiego, Łódź.

Marcińczak S. (2013), Segregacja społeczna w mieście postsocjalistycznym. Bukareszt, Warszawa $i$ Tallin na poczatku XXI wieku, Wyd. Uniwersytetu Łódzkiego, Łódź.

Markowski T., Marszał T. (2006), Metropolie, obszary metropolitalne, metropolizacja. Problemy i pojęcia podstawowe, "Studia KPZK PAN”, Warszawa.

Markowski T., Kaczmarek S., Olenderek J. [red.] (2010), Rewitalizacja terenów poprzemysłowych w Łodzi, „Studia KPZK PAN”, z. 132, Warszawa.

Marszał T. (1995), Szadek. Monografia miasta, Wyd. Uniwersytetu Łódzkiego, Łódź.

Matczak A. (1992), Zmiany w strukturze funkcjonalnej miast Polski w latach 1973-1983, „Acta Universitatis Lodziensis", Folia Geographica, z. 17.

Matczak A. [red.] (1999), Studia nad struktura funkcjonalno-przestrzenna miasta. Przeglą Ła$s k u$, Wyd. Uniwersytetu Łódzkiego, Łódź.

Matczak A. (2007), Małe miasta w badaniach geograficznych, [w:] E. Rydz (red.), Podstawy i perspektywy rozwoju małych miast, Akademia Pomorska w Słupsku, Słupsk, s. 11-30.

Matczak A., Szymańska D. (1997), Studia nad struktura przestrzenno-funkcjonalna miasta. Przykład Brodnicy, Wyd. Uniwersytetu Mikołaja Kopernika, Toruń.

Matykowski R. (1990), Struktura przestrzenna Gniezna i przemieszczenia jego mieszkańców, „Prace Komisji Geograficzno-Geologicznej”, t. 22.

Miszewska B. (1966), Określenie fazy rozwoju morfologicznego bloku miejskiego przyrynkowego (na przykładzie Wrocławia), [w:] S. Golachowski, B. Kostrubiec, A. Zagożdżon (1974), Metody badań geograficzno-osadniczych, PWN, Warszawa. 
Rozwój badań geograficznych nad osadnictwem w Polsce...

Miszewska B. (1971), Analiza morfologiczna Opola, „Studia Społeczno-Ekonomiczne”, z. 2.

Miszewska B., Szmytkie R. (2012), Rozszerzanie się przestrzeni akademickiej we Wroctawiu, „Studia Miejskie”, nr 5, s. 19-32.

Mordwa S. (2013), Przestępczość i poczucie bezpieczeństwa w przestrzeni miasta. Przykład Łodzi, Wydawnictwo UŁ, Łódź.

Mydel R. (1979), Rozwój struktury przestrzennej miasta Krakowa, PAN, Kraków.

Ormicki W. (1932), Miasto jako przedmiot badań geograficznych, „Wiadomości Geograficzne”, nr 2, s. 31-33.

Parysek J. J., Mierzejewska L. (2013), Życie miasta: Studium Poznania. Miasto i jego mieszkańcy, Bogucki Wydawnictwo Naukowe, Poznań.

Parysek J. J., Mierzejewska L. (2014), Życie miasta: Studium Poznania. Infrastruktura miejska, Bogucki Wydawnictwo Naukowe, Poznań.

Przybylska L. (2014), Sakralizacja przestrzeni publicznych w Polsce, Wydawnictwo Uniwersytetu Gdańskiego, Gdańsk.

Pytel S., Zuzańska-Żyśko S. (2010), Rola turystyki w rozwoju miast poprzemysłowych, „Studia Miejskie", nr 2.

Rajman J. (1994), Przemiany społeczno-gospodarcze osadnictwa wiejskiego. Przeglad problematyki badawczej, [w:] S. Liszewski (red.), Geografia osadnictwa i ludności w latach 1918-1993, t. 2, PTG, Łódź, s. 93-109.

Rewieńska W. (1930), Najstarszy Paryż - szkic geograficzny, „Przyroda i Technika”, t. 9, z. 7.

Rewieńska W. (1934a), Z antropogeografii Brasławia, „Wiadomości Geograficzne”, t. 12, nr 10.

Rewieńska W. (1934b), Bereza Kartuska - wybrane rozdziały z antropogeografii miasteczka, „Rozprawy i Materiały”, t. 9, z. 1.

Runge A. (2013), Rola miast średnich w kształtowaniu systemu osadniczego Polski, Uniwersytet Śląski, Katowice.

Rydz E. (1990), Funkcje Koszalina i Stupska w regionalnej sieci osadniczej, Wyższa Szkoła Pedagogiczna, Słupsk.

Rykiel Z. (1978), Miejsce aglomeracji wielkomiejskiej w przestrzeni społeczno-gospodarczej Polski, Instytut Geografii i Zagospodarowania Przestrzennego PAN, „Prace Geograficzne”, nr 128, Warszawa.

Rykiel Z. (1994), Główne kierunki i metody badań w polskiej geografii osadnictwa, [w:] S. Liszewski (red.), Geografia osadnictwa i ludności w niepodległej Polsce. Lata 1918-1993, t. 2: Kierunki badań naukowych, PTG, Łódź, s. 251-264.

Sieradz. Studia nad organizacja przestrzeni miasta (1982), "Acta Universitatis Lodziensis”, Folia Geographica, nr 1.

Simche Z. (1930), Tarnów i jego okolice, Tarnów.

Słodczyk J. (2012), Historia planowania i budowy miast, Uniwersytet Opolski, Opole.

Sobczyński M. (2000), Zróżnicowanie przestrzenne postaw politycznych mieszkańców Łodzi, Wyd. Uniwersytetu Łódzkiego, Łódź.

Sokołowski M. (2006), Funkcje centralne i hierarchia funkcjonalna miast w Polsce, Wyd. Uniwersytetu M. Kopernika, Toruń [rozprawa habilitacyjna].

Staszewska S. (2013), Urbanizacja przestrzenna strefy podmiejskiej polskiego miasta, Bogucki Wydawnictwo Naukowe, Poznań.

Straszewicz L. (1954), Strefa podmiejska Łodzi, „Przegląd Geograficzny”, z. 4.

Straszewicz L. [red.] (1970), Kluczbork. Studium geograficzno-ekonomiczne, Wyd. Śląskie, Katowice.

Straszewicz L. (1972, 1974), Wielkie stolice Europy: Londyn, Moskwa, Paryż, Rzym, PWN, Warszawa.

Straszewicz L. (1985), Strefa podmiejska. Pojęcia i definicje, "Acta Universitatis Lodziensis", Folia Geographica, nr 5, s. 7-16. 
Studia z geografii średnich miast w Polsce. Problematyka Tarnowa (1971), „Prace Geograficzne”, nr 82, IG PAN, PWN, Warszawa.

Suliborski A. (1991), Przemiany struktury funkcjonalnej Łodzi, „Geografia w Szkole”, z. 1.

Suliborski A. (2001), Funkcje i struktury funkcjonalne miast. Studia empiryczno-teoretyczne, Wyd. Uniwersytetu Łódzkiego, Łódź.

Suliborski A. (2010), Funkcjonalizm w polskiej geografii miast. Studia nad geneza i pojęciem funkcji, Wyd. Uniwersytetu Łódzkiego, Łódź.

Suliborski A., Wójcik M. [red.] (2014), Dysproporcje społeczne i gospodarcze w przestrzeni Łodzi. Czynniki, mechanizmy, skutki, Wyd. Uniwersytetu Łódzkiego, Łódź.

Szajnowska-Wysocka A. (1995), Podstawy zorganizowania miast Konurbacji Górnoślaskiej, „Prace Naukowe Uniwersytetu Śląskiego w Katowicach”, nr 147.

Szkurłat E. (2004), Więzi terytorialne młodzieży z miastem. Uwarunkowania. Przemiany. Wyd. Uniwersytetu Łódzkiego, Łódź.

Szmytkie R. (2014), Metody analizy morfologii i fizjonomii jednostek osadniczych, „Rozprawy Naukowe Instytutu Geografii i Rozwoju Regionalnego Uniwersytetu Wrocławskiego", nr 35 .

Szponar A. (2003), Fizjografia urbanistyczna, Wyd. Naukowe PWN, Warszawa.

Szulc H. (1994), Osadnictwo wiejskie Polski w pracach geograficzno-historycznych w latach 19181993, [w:] S. Liszewski (red.), Geografia osadnictwa i ludności w latach 1918-1993, t. 2, PTG, Łódź, s. 72-92.

Szulc H. (1995), Morfogeneza osiedli wiejskich w Polsce, Instytut Geografii i Zagospodarowania Przestrzennego PAN, „Prace Geograficzne”, nr 163, Wrocław.

Szulc H. (2002), Atlas historyczny wsi w Polsce, Instytut Geografii i Zagospodarowania Przestrzennego PAN, Warszawa.

60 Szymańska D. (2008), Urbanizacja na świecie, Wyd. Naukowe PWN, Warszawa.

Szymańska D. (2009), Geografia osadnictwa, Wyd. Naukowe PWN, Warszawa.

Szymańska W. (2006), Formy zagospodarowania terenów powojskowych na przykładach: Wałcza, Szczecinka i Lęborka, XIX Konwersatorium Wiedzy o Mieście, Łódź.

Szymańska W. (2011), Społeczna przestrzeń w średnich miastach na Pomorzu (przykład Lęborka, Szczecinka i Wałcza), Akademia Pomorska w Słupsku, Słupsk.

Tkocz J. (1971), Rozłogi województwa opolskiego. Studium genezy i oceny, Instytut Śląski, Wrocław-Opole.

Tkocz J. (1998), Organizacja przestrzenna wsi w Polsce, Wyd. Uniwersytetu Śląskiego, Katowice.

Wejchert K. (1947), Osiedla miejskie - struktura zawodowa - typy miast, Warszawa.

Werwicki A. (1973), Struktura przestrzenna średnich miast ośrodków wojewódzkich w Polsce, Instytut Geografii i Zagospodarowania Przestrzennego PAN, „Prace Geograficzne”, nr 101, Wrocław.

Węcławowicz G. (1988), Struktury społeczno-przestrzenne w miastach Polski, „Prace habilitacyjne IG PAN", Wyd. Ossolineum, Wrocław.

Węcławowicz G. (2003, 2007), Geografia społeczna miasta, Wyd. Naukowe PWN, Warszawa.

Winid W. (1937), Miasto i wieś w krajobrazie geograficznym i ich rola w życiu gospodarczym, „Czasopismo Geograficzne”, t. 15.

Witkowski S. (1967), Struktura przestrzenna miasta na przykładzie Radomia, Warszawa.

Wojnarowska A., Kozłowski S. (2011), Rewitalizacja zdegradowanych obszarów miejskich. Zagadnienia teoretyczne, Wyd. Uniwersytetu Łódzkiego, Łódź.

Wolaniuk A. (1994), Przemieszczanie centrum wielkiego miasta - przykład Łodzi, VII Konwersatorium Wiedzy o Mieście, red. J. Kaczmarek, Łódź.

Wolaniuk A. (1997), Funkcje metropolitalne Łodzi i ich rola w organizacji przestrzeni, „Szlakami Nauki", nr 25, ŁTN, Łódź. 
Rozwój badań geograficznych nad osadnictwem w Polsce...

Wolaniuk A. (2010), Uniwersytety $i$ ich rola w organizacji przestrzeni, Wyd. Uniwersytetu Łódzkiego, Łódź.

Wolaniuk A. [red.] (2014), Centra i peryferia w okresie transformacji ustrojowej, XXVII Konwersatorium Wiedzy o Mieście, Łódź.

Wójcik M. (2012), Geografia wsi w Polsce. Studium zmiany podstaw teoretyczno-metodologicznych, Wyd. Uniwersytetu Łódzkiego, Łódź.

Wróbel A. (1970), Baza ekonomiczna miasta a potencjał ludnościowy , "Przegląd Geograficzny”, t. $42, z .2$.

Wróbel A. (1980), Modele bazy ekonomicznej jako narzędzie analizy planowania, „Przegląd Geograficzny", t. 52, z. 4 .

Zaborski B. (1926), O kształtach wsi w Polsce i ich rozmieszczeniu, „Prace Komisji Etnograficznej Polskiej Akademii Umiejętności", nr 1.

Zajchowska S. (1967), Podział funkcyjny miast Wielkopolski, „Czasopismo Geograficzne”, t. 35. z. 1.

Stanisław Liszewski, prof. dr hab., Instytut Geografii Miast i Turyzmu,

Wydział Nauk Geograficznych, Uniwersytet Łódzki 